\title{
Consideration of cognitive styles as a method of solving the problem of intensification of professional training of future software engineers
}

\author{
A. A. Sender \\ Melitopol State Pedagogical University named after Bohdan Khmelnytsky, \\ Department of Informatics and Cybernetics, Melitopol, Ukraine. \\ Corresponding author. E-mail: sender@mdpu.org.ua, ORCID: 0000-0002-8741-5625.
}

Paper received 12.12.20; Accepted for publication 23.12.20.

\begin{abstract}
https://doi.org/10.31174/SEND-HS2020-242VIII42-10
\end{abstract}
\begin{abstract}
The article considers the possibility of using the approach taking into account the cognitive aspect of the style of teaching students in information technology, in order to solve the problems of intensification of professional training. The main means of taking into account cognitive styles, the author notes the testing of students to determine their psychological characteristics and further individualization of the educational vector according to the results. According to the author, the results of testing students of III and IV courses of IT-specialties indicate a tendency of predominance of synthetic methods of information processing.
\end{abstract}

Keywords: software engineer; quality of education; intensification; institution of higher education, analysis, cognitive styles.

Introduction. The current tendency to intensively increase the field of information technology (IT) in the vector of dominance, among others, is actively manifesting itself in Ukraine and the world. This trend is manifested primarily through the constant development and direct implementation of high-quality IT products by Ukrainian specialists, which in turn raises Ukraine among the countries participating in international grant and private projects. This growth in the popularity of Ukrainian developments creates the conditions for the constant growth of labor market demand for highly qualified IT professionals and necessitates the acceleration of the pace of training and intensification of training in general. An additional problem is the need of employers for IT professionals who, in addition to knowledge and skills directly in the field of IT, have a high level of foreign language skills, leadership and management skills, high skills for self-development and cover knowledge in various areas of IT development. These factors create a need to explore ways to intensify the educational process and develop new approaches to solving the problem of intensifying the educational process of future software engineers in the study of general and professional disciplines.

Analysis of research and publications. Analyzing scientific developments in the vector of intensification, the introduction of differentiated learning can be considered a relevant and priority approach. As noted in the work of $\mathrm{T}$. Santangelo and C. Tomlinson [1], the main purpose of differentiated learning can be considered the task of maximizing the learning potential of each individual student with prior experience of each student, they stressed the need to focus teachers on three important characteristics: willingness to learn, interest in the learning process and the direct psychological profile of the student. However, the study focuses on taking into account the teaching experience in groups of students who have already been trained by certain teachers before and focuses on the mental abilities of students, without taking into account the personal characteristics of the student. The studies of A. Margaryan, M. Bianco, and A. Littlejohn [2] can be considered in more detail, emphasizing the need to take into account the needs of each student, but the authors did not disclose the specifics of this approach, which encourages further research. Important for further research was the work of M. N. Suprayogi, M. Valcke and R. Godwin [3], who delved into the study of psychological characteristics of students and stressed that differentiated learning is primarily associated with a complex set of variables, such as the student's effectiveness, belief in the fidelity of the teaching material, teaching experience of the teacher, professional development of the teacher and his certification, but these aspects are aimed more at the professional characteristics of the teacher, repelling the need to determine the student's personality.

The aim of the study. The purpose of the study is to analyze the problem of intensification of education and the possibility of using the factor of cognitive styles as a means of solving the problem of intensification of training of future software engineers.

The methodology of study. To achieve this goal, information support tools and research methods were used:

theoretical: theoretical analysis of sources on the intensification of the educational process, its problems and implementation, research of the possibility of using cognitive styles in the educational process;

empirical: design and modeling of learning outcomes using cognitive styles; interpretive methods that make it possible to generalize and explain the established facts and their relationship.

Research results and their discussion. In the framework of this study, the main task is to determine the possibility of intensifying the training of future software engineers and accelerate the process of mastering their general and professional skills, but at the beginning it would be appropriate to identify existing methodological approaches to intensifying education using cognitive styles. In this context, conducting an analysis of the modern market, it can be argued that the development and implementation of new concepts of learning and development depend on the training of future software engineers in higher education. Note that the main modern areas that optimize training are the cognitive approach and procedural-cognitive approach. Analyzing the possibilities of procedural-cognitive approach, from the point of view of studying the disciplines of the IT sphere, it is possible to emphasize the presence of non-obvious, but significant impact on the quality of learning different programming languages. In the educational process, this approach focuses on language learning and determines the method of its teaching. First of all, it involves the development of intellectual abilities (reflection, interpretation, ambiguous vision) in the field of language acquisition, as it is generally obvious that a simple "learn- 
ing" of language (programming language) is not enough for its proper and global use in a constantly expanding functionality and the needs of the IT environment. To solve the main task of training future software engineers, namely the acquisition by students of general professional and professional skills required by a highly qualified IT specialist, various individual training programs, methods, techniques can be used to outline a certain learning style. In the research of world educators and psychologists, the style of studying professional disciplines is perceived as one of the most important factors in how well students master certain skills. Teaching style determines the specific set of actions used to achieve the goal of teaching each individual discipline within the educational program. At the same time, researchers use the concept of "cognitive style", which they usually define as the preferred mode of perception, memorization, organization, processing and presentation of information [4]. Today it is a well-known fact that learning style is a multidimensional phenomenon and takes on a general social character, which in turn creates the conditions for a quality learning process usually requires a comprehensive and multidimensional vision of situations, teaching methods and approaches to learning. This in turn requires a comprehensive assessment of the student's abilities, and taking into account his strengths and weaknesses. This is what creates the conditions for the introduction of a factor of differentiation of education and taking into account the cognitive characteristics of students before determining approaches to learning. In addition, analyzing the scientific achievements of world scientists, we would like to note the work of D. Grossmann [5], who noted in his work that cognitive style is an integral part of learning style. Thus, it creates the conditions for the assertion of the need to include cognitive style in the style of teaching professional disciplines.

Analysis of the scientific literature shows that the range of cognitive parameters is very wide and includes the following approaches to the perception of information: independent or dependent, analytical or synthetic, reflexive or impulsive and many others. In addition, the analysis of the scientific literature revealed the connection of the cognitive aspect with the specifics of the professional activities of IT professionals. An example of this connection is the fact that cognitive styles and personality traits have the greatest impact on each of the four stages of programming processes (problem identification, software development, coding, debugging and testing), because the cognitive style of the developer significantly affects the path and the pace of future development. This means that the strengths of the personal developer can significantly affect the performance of software engineers.

There is no doubt that the teaching of professional disciplines for future software engineers in higher education is based on the content of their professional disciplines, which in turn allows you to create a virtual professional environment by simulating various problem or production situations. Using methods of adapting the teaching strategy in each group to the cognitive characteristics of students, can solve a significant share of perception needs, which will allow students to effectively develop their professional competencies, allowing them to use their personal qualities as effectively as possible and function in culturally diverse academic and professional environments.
Having analyzed the scientific developments for the training of future software engineers, we note that in his works V. S. Kruglik [7], V.V. Osadchy [8], I.V. Krasheninnik [9], noted among a fairly wide range of requirements for future software engineers, the priority can be conditionally identified as:

- $\quad$ skills of creating and debugging software;

- computer equipment design and maintenance

skills;

- $\quad$ ability to maintain information;

- $\quad$ ability to identify vulnerabilities in the developed software;

- $\quad$ ability to develop and maintain web-resources for the Internet;

- $\quad$ skills to configure the protection of internal systems of companies, etc.

This list allows us to say that the specifics of the professional activities of future software engineers, primarily focused on the following types of human activity: perception, processing and implementation of textual, symbolic, graphical information presented orally or in writing. This definition makes it possible to emphasize that in general the professional activity of future software engineers coincides significantly with the educational activities of students of most specialties, i.e. focuses on the mental and psychological aspects of the perception of ambiguous information. This once again confirms the relevance of using methods of taking into account cognitive styles in the training of future software engineers, which will be used by students, both in education and in further professional activities. Thus, differentiated training for future software engineers should be based on the cognitive aspect of the study of general and professional disciplines. Thus, we see it appropriate to identify and analyze the features of the cognitive aspect of the teaching style of professional disciplines in differentiated learning of IT students at the university level and highlight ways to individualize the learning process by taking into account the cognitive styles of students.

As part of the study, we conducted an experiment on the basis of Melitopol State Pedagogical University named after Bohdan Khmelnytsky, in which we developed and tested students of IT-specialties in order to determine the dominant approach to information perception:

- $\quad 46$ third-year students $(24,1 \%$ of students have a dominant auditory approach, $11,2 \%$ of students have a visual approach and $6,8 \%$ of students have a dominant kinesthetic approach).

- 52 fourth-year students $(21,5 \%$ of students have a dominant auditory approach, $9,8 \%$ of students have a visual approach and $6,3 \%$ of students have a dominant kinesthetic approach).

The majority of third-year IT students $(57,9 \%)$ and fourth-year IT students $(62,4 \%)$ showed the results of the emphasis on a mixed sensory approach. Turning to the work of D. G. Tight [6. p. 35], who in his study noted that a mixed sensory approach is the ability to function in more than one approach to information perception.

Analyzing the scientific literature, we can note that traditionally in the scientific literature, people who operate simultaneously with the three main approaches are called "digital", "auditory-digital" or "discrete". People with this approach to the perception of information are able to perceive it through logical thinking, using numbers, signs and 
logical inferences in thinking.

During our experiment:

- $\quad$ among third-year students of IT-specialties, 10,2\% have equally developed visual, auditory and kinesthetic approaches to information perception, $11,2 \%$ - visual and kinesthetic approaches to information perception, $14,1 \%$ visual and auditory approaches to information perception, $22,5 \%$ - with auditory and kinesthetic approaches to information perception.

- among fourth-year students of IT-specialties $17,5 \%$ have equally developed visual, auditory and kinesthetic approaches to information perception, $14,8 \%$ - visual and kinesthetic approaches to information perception, $18,2 \%$ - visual and auditory approaches to information perception, $21,9 \%$ - with auditory and kinesthetic approaches to information perception.

The comparison of students of III and IV courses of ITspecialties showed that the dominant sensory approaches to

Testing of 46 third-year IT students to determine the dominant method of perception and processing of information in the learning process showed that students can be divided into those who dominate in the synthetic method of information processing $-54,1 \%$, analytical method of information processing $-10,7 \%$ or combine both methods of information processing - 33,2\%.

Among 52 fourth-year IT students, 57,1\% have a predominant synthetic method of information processing, cessing, and $29,3 \%$ have a mixed synthetic-analytical method of information perception and processing.

The results of testing students of third-year and fourthyear students of IT-specialties showed a tendency of predominance of synthetic methods of information processing, as well as mixed synthetic-analytical methods of information processing. The test results, in turn, allowed to adthe perception of information are auditory and mixed. $13,6 \%$ have an analytical method of information pro-

just the strategy of the educational process and deepen the vector of problem situations and project approach, which significantly accelerated the process of students 'perception of information, improve students' motivation to learn and general attitude to the course.

Conclusions. The result was the confirmation of the possibility of taking into account cognitive styles in the preparation of future software engineers for professional activities and the confirmation of the factor of influencing cognitive styles on the quality of the educational process by facilitating the perception of information by students. Therefore, we consider it appropriate to recommend the construction of the educational process of students with the choice of strategy to promote the development of their cognitive potential. The results of the experiment show that due to the testing conducted before the training, conditions were created for adjusting the strategy of the educational process and deepening into the vector of problem situations and project approach, which significantly accelerated the process of students 'perception of information, improve students' motivation to learn. and general attitude to the course. This work does not cover all the features of cognitive styles in the educational process, but updates and summarizes existing research, confirming them on the basis of Melitopol State Pedagogical University named after Bohdan Khmelnytsky experiment to determine approaches to the perception and processing of information by students of third-year and fourth-year student's IT-specialties. In further research, we consider it relevant and plan to develop guidelines for teachers to develop educational and methodological complexes, refine and expand testing to better cover the cognitive characteristics of students and conduct an experiment to determine the level of influence of students' cognitive styles in training future software engineers.

\section{LITERATURE}

1. Santangelo T., Tomlinson C. A. Teacher educators' perceptions and use of differentiated instruction practices: An exploratory investigation //Action in Teacher Education. 2012. V. 34. №. 4. pp. 309-327.

2. Margaryan A., Bianco M., Littlejohn A. Instructional quality of massive open online courses (MOOCs) //Computers \& Education. 2015. V. 80. pp. 77-83.

3. Suprayogi M. N., Valcke M., Godwin R. Teachers and their implementation of differentiated instruction in the classroom //Teaching and Teacher Education. 2017. V. 67. pp. 291-301.

4. Dörnyei Z. The psychology of the language learner: Individual differences in second language acquisition. Routledge, 2014.

5. Grossmann D. A study of cognitive styles and strategy use by successful and unsuccessful adult learners in Switzerland // Unpublished MA Thesis, School of Humanities of the University of Birmingham. 2011.

6. Tight D. G. The role of perceptual learning style preferences and instructional method in the acquisition of L2 Spanish vocabulary: dis. University of Minnesota, 2007.

7. Круглик В. С. Веб-орієнтовані навчальні середовища у професійній підготовці майбутніх інженерів-програмістів //Інформаційні технології в освіті та науці: зб. наук. пр. 2017. T. 1. №. 9. С. 153-157.

8. Круглик В. С., Осадчий В. В. Аналіз змісту професійної підготовки інженерів-програмістів //Проблеми інженернопедагогічної освіти. 2016. №. 52-53. С. 101-110.

9. Осадчий В. В., Крашеніннік І. В. Формування змісту освітніх програм підготовки майбутніх інженерів-програмістів за скороченим терміном навчання на основі аналізу ринку праці //Інформаційні технології і засоби навчання. 2017. №. 58, вип. 2. С. 11-25.

\section{REFERENCES}

7. Kruglik, V. S. (2017). Web-based learning environments in the training of future software engineers. Information technologies in education and science: coll. Science. pr., 1 (9), 153-157. [in Ukrainian].

8. Kruglik, V.S., \& Osadchiy, V.V. (2016). Analysis of the content of professional training of software engineers. Problems of engineering and pedagogical education, (52-53), 101-110. [in

\section{Ukrainian].}

9. Osadchy, V.V., \& Krasheninnik, I.V. (2017). Formation of the content of educational programs for the training of future software engineers for a reduced period of study based on the analysis of the labor market. Information technologies and teaching aids, 58 (2), 11-25. [in Ukrainian]. 